Bangl. J. Vet. Med. (2011). 9 (1) : 73-78

\title{
PREVALENCE OF SUBCLINICAL MASTITIS IN DAIRY COWS IN SELECTED AREAS OF BANGLADESH
}

\author{
M. A. Islam*, M. Z. Islam, M. A. Islam, M. S. Rahman and M. T. Islam \\ Department of Medicine, Faculty of Veterinary Science, Bangladesh Agricultural University, \\ Mymensingh-2202, Bangladesh
}

\begin{abstract}
This research was carried out to determine the prevalence of subclinical mastitis in lactating Dairy Cow of Bangladesh Agricultural University dairy farm (BAUDF) and rural areas of Tangail sadar upazila of Bangladesh during the period of July 2009 to April 2010. A total of 200 milk samples (40 from BAUDF and 160 from Tangail sadar upazila) were collected for this study which were subjected to physical examination and subsequently screened for subclinical mastitis using three indirect tests viz. White Side Test (WST), California Mastitis Test (CMT), and Surf Field Mastitis Test (SFMT). Overall prevalence of subclinical mastitis (SCM) in lactating dairy cows found in this study was $29 \%$. Cows were infected with SCM $29.5 \%, 27.5 \%$ and $25.5 \%$ detection by CMT, WST and SFMT respectively. Higher prevalence of SCM was detected in milch crossbred cows (36.36\%) in comparison to local bred cows $(24.61 \%)$ maintained under extensive management system in Rural area of Tangail sadar upazila. The prevalence of SCM was recorded in $31.58 \%, 30.76 \%$ and $68.75 \%$ in cows of local area of Tangail sadar upazila, and $25.0 \%, 40.0 \%$ and $71.42 \%$ in cows of BAU,DF during the early, mid and late stages of lactation respectively. The highest prevalence of SCM was recorded during the early lactation stage in both the local breed cows (30.0\%) and cows of BAUDF (45.83\%) in comparison to their respective mid and late stages of lactation. The prevalence of SCM was highest in lactating cows having third lactation and high yielding (cows produced $>10$ liter milk per day) both in local breed and crossbred cows.
\end{abstract}

Key words: Subclinical mastitis, prevalence, dairy cows

\section{INTRODUCTION}

Mastitis is a common disease entity of dairy cows, accompanied by physical, chemical, pathological and bacteriological changes in milk and glandular tissue (Samad, 2008). The disease is usually classified as subclinical, acute, subacute and chronic based on aetio-pathological findings and observations (Tripathi and Chaltopadhyay, 1993). Mastitis, the inflammation of mammary gland remains a serious problem for dairy animals industry and has very serious ramifications for dairy industry worldwide. The subclinical form of mastitis in dairy cows is important because this form is (a) 15 to 40 times more prevalent than the clinical form, (b) it usually precedes the clinical form, (c) it is of long duration, (d) it is difficult to detect, (e) It reduces milk production, and (f) it adversely affects milk quality (Seegers et al., 2003). Several causative agents and predisposing factors have been implicated in mastitis in dairy cows including bacterial, mycoplasmal and yeast pathogens (Egwu et al., 1994). Staphylococcus sp. is the main aetiological agents of clinical and subclinical mastitis in cows while, S. aureus and Escherichia coli are most commonly isolated pathogen from the clinical mastitis, coagulase negative Staphylococci (CNS) are the most frequently isolated pathogens from the subclinical cows mastitis (Contreras et al., 2003). Predisposing factors such as poor management and hygiene, teat injuries and faulty milking machines are known to hasten the entry of infectious agents and the course of the disease (Majic et al., 1993).

It is now a well known fact that the subclinical mastitis (SCM) is more serious and is responsible for much greater loss to the dairy industry (Kader et al., 2002). The SCM can be known only after laboratory examination, as there are no gross inflammatory changes in the udder tissue. Singh and Singh (1982) reported more than three times losses due to SCM, as compared to clinical mastitis (CM). Besides causing huge losses to milk production, the subclinically affected animals remain a continuous source of infection to other herd mates. If the infection persists for longer periods, then it may form a fibrous tissue barrier between the organisms and the antibiotic preparations, thus, limiting their efficacy. It is, therefore, important to know the prevalence of SCM in dairy herds and delineate the important factors responsible for it. Therefore, the present research work was undertaken with the aim to detect the prevalence and risk factors of subclinical mastitis (SCM) in lactating cows in Bangladesh Agricultural University Dairy Farm (BAUDF) and Sadar upazila of Tangail district in Bangladesh.

*Corresponding e-mail address: maislam77@ gmail.com 


\section{A. Islam and others}

\section{MATERIALS AND METHODS}

\section{Study area and period}

The present research was carried out in dairy cows of Bangladesh Agricultural University Dairy Farm (BAUDF) and rural areas of Tangail sadar upazila. All the tests were performed at field condition immediately after collection of milk during the period from July 2009 to April 2010.

\section{Husbandry and management system}

Crossbred dairy cows used in this study were managed under semi intensive husbandry systems at BAUDF. They are provided with green grass in addition to natural pasture and concentrate diet and are kept together in common shed but at peri-parturient period (advanced pregnancy and early lactating stage) they are maintained in separate stalls. Local breed cow at rural areas Tangail sadar upazila reared under extensive husbandry system with ground muddy floor and without concentrated feed.

\section{Survey design and sampling}

A cross-sectional observational study was conducted in BAUDF and rural area of Tangail sadar upazila. Milk samples were collected by owner and by the farm attendants instructing them to soak the teat with $70 \%$ ethanol and drying off by tissue paper, one to two drops of milk were discarded and then $10 \mathrm{ml}$ of milk taken into numbered sterilized test tubes with rubber cap to perform other tests.

\section{Questionnaire-based data collection and processing}

Data from each animal and herd were collected using a questionnaire. Parameters studied were age, breed, number of parity, lactation stage and per day milk production. Age, parity, lactation stage were determined by asking owner and farm attendant and also from the farm records where available. The statistical analysis of collected data was performed by using SPSS version 11.5.

\section{Physical examination of milk sample}

Immediately after collection, milk samples were subjected to physical examination with naked eyes to detect any abnormalities in colour, odour, consistency and presence of clot, blood, flakes and any other visible abnormalities.

\section{White Side Test (WST)}

The WST was performed as per procedure described by Kahir et al., (2008), in brief, after thorough mixing avoiding violent shaking, $50 \mu \mathrm{l}$ (five drops) of milk were placed on a glass slide with a dark background by micropipette. Subsequently $20 \mu \mathrm{l}$ of WST reagent $(4 \% \mathrm{NaOH})$ were added to the milk sample and the mixture was stirred rapidly with a toothpick for 20-25 seconds. A breaking up of milk in flakes, shreds and viscid mass was indicative of positive reaction. On the other hand, milky and opaque and entirely free of precipitant was indicative of negative reaction. The grading of positive WST scores was shown in Table 1.

Table 1. Grading of the White Side Test (WST) scores

\begin{tabular}{|c|c|c|}
\hline Visible reaction & Interpretation & Symbol \\
\hline Mixture is milky and opaque and entirely free of precipitant. & Negative & - \\
\hline $\begin{array}{l}\text { The background is less opaque but still somewhat milky, with larger } \\
\text { particles of coagulated materials being present and thickly scattered } \\
\text { through the area. A slight degree of clumping is observed. }\end{array}$ & Weak positive & $1+$ \\
\hline $\begin{array}{l}\text { The background is more watery and large clumps of coagulated } \\
\text { materials are present. If the stirring has been rapid, fine threads or } \\
\text { strings may be present. }\end{array}$ & Distinct & $2+$ \\
\hline $\begin{array}{l}\text { The background is very watery and whey-like, with large masses of } \\
\text { coagulated material forming into strings and shreds. }\end{array}$ & Strong positive & $3+$ \\
\hline
\end{tabular}




\section{Surf Field Mastitis Test (SFMT)}

This test was performed and scored following the method described by Muhammad et. al. (1995) in brief, about $2 \mathrm{ml}$ milk was drawn from bottle into test cup and an estimated $2 \mathrm{ml}$ reagent was squirted from a polyethylene wash bottle. Mixing was accomplished by gentle circular motion of the paddle in a horizontal plane for few seconds. The reaction developed almost immediately with milk containing a high concentration of somatic cells. The peak of reaction was obtained within 30 seconds and immediately scored as $1+, 2+$ and $3+$.

\section{California Mastitis Test (CMT)}

The procedure of CMT was followed in this study as per manufacturer's instruction (Leukocyst ${ }^{\circledR}$, Synbiotics Corporation, France). In brief, about $2 \mathrm{ml}$ milk was drawn from bottle into the cup and an estimated equal volume of CMT reagent was squirted from a polyethylene wash bottle. Mixing was accomplished by gentle circular motion of the paddle in a horizontal plane for few seconds. The reaction developed almost immediately with milk containing a high concentration of somatic cells. The peak of reaction was obtained within 10 seconds and scored. The CMT reaction/ results were read immediately as per manufacturer's recommendation and were scored for each half gland (teat) depending on the amount and thickness of gel formed as described by Ikram (1997) as shown in Table 2.

Table 2. Scoring of California mastitis test results

\begin{tabular}{|c|c|c|c|c|}
\hline \multicolumn{3}{|l|}{ Reading } & \multicolumn{2}{|l|}{ Interpretation } \\
\hline \multirow[t]{2}{*}{ Aspect } & \multicolumn{2}{|l|}{ Score } & \multirow[t]{2}{*}{ Infection } & \multirow{2}{*}{$\begin{array}{l}\text { Related with the } \\
\text { average cellular } \\
\text { numeration }\left(\times 10^{3} / \mathrm{ml}\right)\end{array}$} \\
\hline & Value & Cross & & \\
\hline Consistency normal or Gray color & 0 & (0) & Absent & 100 \\
\hline $\begin{array}{l}\text { Light gel disappearing after stirring or } \\
\text { Purplish gray color }\end{array}$ & 1 & $( \pm)$ & $\begin{array}{l}\text { Infection risk by minor } \\
\text { pathogenic }\end{array}$ & 300 \\
\hline $\begin{array}{l}\text { Light persistent gel-crumbly } \\
\text { filaments or Purple gray }\end{array}$ & 2 & $(+)$ & Subclinical mastitis & 900 \\
\hline $\begin{array}{l}\text { Immediate thickening viscous cluster } \\
\text { at the bottom of the well }\end{array}$ & 3 & $(++)$ & Sub clinical mastitis & 2700 \\
\hline $\begin{array}{l}\text { Thick gel consistency of egg white } \\
\text { color dark purple }\end{array}$ & 4 & $(+++)$ & $\begin{array}{l}\text { Subclinical mastitis near } \\
\text { the clinical expression }\end{array}$ & 8100 \\
\hline
\end{tabular}

\section{RESULTS AND DISCUSSION}

Of 200 samples collected from BAUDF and rural areas of Tangail sadar upazila and were examined by CMT, SFMT and WST, of which yielded an overall prevalence of SCM as $29 \%(\mathrm{n}=58), 25.5 \%(\mathrm{n}=55)$ and $27.5 \%$ $(\mathrm{n}=51)$. Findings of the present study are supported by earlier findings of Kader et al. (2002) who reported $46.6 \%$ SCM in Bangladesh in cows on bacteriological examination and a higher prevalence $(54.0 \%)$ of SCM in cows in India were reported by Singh and Baxi (1988).

\section{Breed related prevalence}

All the cows of BAUDF were cross breed and show 37.5\% positive reaction whereas local and cross breed of Tangail sadar Upazila show $24.6 \%$ and $36.66 \%$ positive reaction. Of 70 crossbred cows screened for SCM showed $37.5 \%$ and $36.66 \%$ in BAU,DF and in Tagail sadar upazial whereas local breed cows showed $24.61 \%$ positive reaction for SCM (Table 3). The results of this study is higher than that of Rabbani (2008) who reported $20.31 \%$ in Holstein Friesian cross cows and $13.24 \%$ in Red Chittagong cows and of Prodhan et al. (1996) who reported $16.52 \%$ and $15.77 \%$ incidence of SCM with WST and CMT at Sirajganj. 


\section{A. Islam and others}

Table 3. Breed wise prevalence of subclinical mastitis (SCM) in local and crossbred cows

\begin{tabular}{|lccccc|}
\hline & \multicolumn{2}{c}{ BAUDF } & & \multicolumn{2}{c|}{ Tangail sadar upazila } \\
\cline { 2 - 3 } \cline { 5 - 5 } & Local breed & Cross breed & & Local breed & Cross breed \\
\hline No of samples tested & 0 & 40 & 130 & 30 \\
Positive cases & 0 & 15 & 32 & 11 \\
Prevalence & 0 & $37.5 \%$ & & $24.61 \%$ & $36.66 \%$ \\
\hline
\end{tabular}

\section{Age wise prevalence}

The prevalence of SCM was recorded as $22.22 \%, 27.94 \%, 21.21 \%$ and $18.18 \%$, respectively at the age group of 3 years to 5 years, $>5$ years to 8 years, $>8$ years to 12 years and $>12$ years in local breed cows. The prevalence of SCM was recorded $33.33 \%, 40.90 \%, 28.57 \%$ and $0.00 \%$ respectively at the age group of 3 years to 5 years, $>5$ years to 8 years, $>8$ years to 12 years and $>12$ years in cross breed cows (Table 4 ).

Table 4. Age wise prevalence of SCM in dairy cows

\begin{tabular}{|lccccc|}
\hline Age groups & \multicolumn{2}{c}{ Local breed } & & \multicolumn{2}{c|}{ Cross breed } \\
\cline { 2 - 3 } \cline { 5 - 6 } & Sample tested & Positive $(\%)$ & & Sample tested & Positive $(\%)$ \\
\hline 3 years to 5 years & 18 & $4(22.22)$ & & 18 & $6(33.33)$ \\
$>$ 5 years to 8 years & 68 & $19(27.94)$ & & 44 & $18(40.90)$ \\
$>$ 8 years to 12 years & 33 & $7(21.21)$ & & 7 & $2(28.57)$ \\
$>$ 12 years & 11 & $2(18.18)$ & & 1 & $0(0.00)$ \\
\hline
\end{tabular}

\section{Parity related prevalence}

The prevalence of SCM in local breed cows was recorded in $18.75 \%, 22.22 \%, 29.55 \%, 26.66 \%, 18.18 \%$ and $23.52 \%$ during the parity numbers $1,2,3,4,5$ and 6 , respectively. The parity wise prevalence of SCM in cross breed cows were $28.57 \%, 36.84 \%, 47.05 \%, 36.36 \%, 33.33 \%$ and $33.33 \%$ during the parity numbers $1,2,3,4,5$ and 6, respectively (Fig. 1).

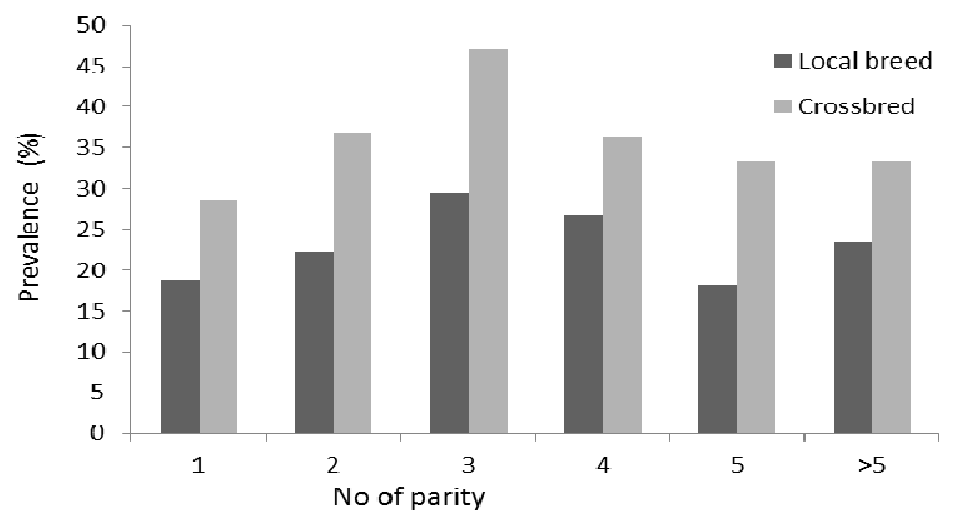

Fig. 1. Parity related prevalence of SCM in dairy cows

It indicates that the prevalence of SCM was found highest at $3^{\text {th }}(29.55 \%)$ and $(47.05 \%)$ parity in local and cross breed cows respectively in comparison to $1^{\text {st }}$ and $2^{\text {nd }}$ parity but increasing tendency was recorded with increase of parity. This observation supports with the reports of Rasool et al. (1985) and Devi et al. (1997) who reported an increasing prevalence of SCM with advancing parity. 


\section{Lactation stage related prevalence}

It appears from the Table 5 that, all three stages of lactation in both the local cows and cross breed cows affected with SCM. The prevalence of SCM was recorded in $30.00 \%, 17.14 \%$ and $25.45 \%$ in local breed cows, and $45.83 \%, 31.58 \%$ and $33.33 \%$ in cross breed cows during the early, mid and late stages of lactation, respectively. The highest prevalence of SCM was recorded during the early lactation stage in both the local breed cows $(30.0 \%)$ and cross breed cows $(45.83 \%)$ in comparison to there respective mid and early stages of lactation. The overall prevalence of SCM on the basis of lactation stage in cows showed that all the three lactation stages had SCM but there was a tendency to decrease the prevalence of SCM from early (45.83\%) to mid (31.58\%) but more in late stage than mid (33.33\%) stage.

Table 5. Lactation stage related prevalence

\begin{tabular}{|lccccc|}
\hline Stage of lactation & \multicolumn{2}{c}{ Local breed } & & \multicolumn{2}{c|}{ Cross breed } \\
\cline { 2 - 3 } \cline { 5 - 6 } & Sample tested & Positive $(\%)$ & & Sample tested & Positive (\%) \\
\hline Early (60-90 days) & 40 & $6(30.00)$ & & 24 & $11(45.83)$ \\
Mid (91-180 days) & 35 & $14(25.45)$ & & 19 & $6(31.58)$ \\
Late (> 180 days) & 55 & $14.14)$ & 27 & $9(33.33)$ \\
\hline
\end{tabular}

The prevalence of SCM in the early, mid and late stage lactation in local breed cows was 30\%, 17.14\% and $25.45 \%$, respectively. Similarly, it was recorded as $45.83 \%, 31.58 \%$ and $33.33 \%$ in the early (mid) and (late) stages of lactations in cross breed cows. It indicates that the prevalence of SCM was found highest at early stage in both the local $(30 \%)$ and cross breed $(45.83 \%)$ cows in comparison to mid and late stages of lactations. There results contradicts the earlier finding of Rahman et al., (1997) who reported highest prevalence of SCM during the $3^{\text {rd }}$ months $(34 \%)$ of lactation. However, these results agree with Pal and Verma (1988) who reported lower prevalence of SCM in stages of lactation above five months. Review of literature revealed that the higher incidence of CM usually occurred during early stage of lactation due to high yielding enlarged status of udder which is particularly prone to infection and inflammatory process became of physiological stress strain of heavy milk production, but the prevalence of SCM could be high at late stage of lactation.

\section{Prevalence of SCM on the basis of milk production}

The local breed cows were grouped into five and cross breed cows were grouped into five on the basis of milk production and the highest prevalence of SCM was recorded in cows with low milk production in both the local breed cows and cross breed cows. The prevalence of SCM in local breed cows was recorded in 13.04\%, 20.75\% and $30.95 \%, 37.5 \%$ and $50 \%$, respectively, $0.5-1$ lit,> lit 1-2,> lit 2-5, lit $>5-10$ lit milk production per day, whereas the prevalence of SCM in cross breed cows were $28.57 \%, 35.48 \%, 40.00 \%$ and $42.85 \%$, respectively $>1-2$ lit $>2-5$ lit, $>5-10$, and >10 lit milk production per day (Fig 2.).

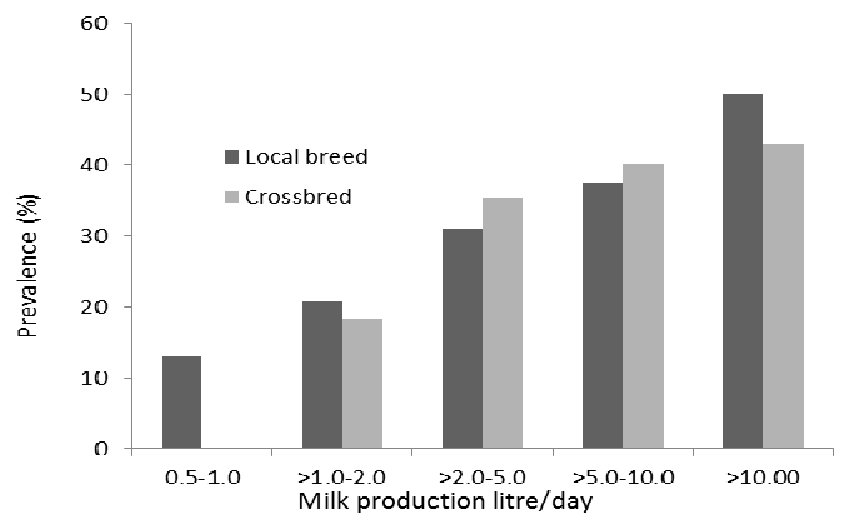

Fig. 2. Milk production related prevalence of SCM in dairy cows 


\section{A. Islam and others}

The prevalence of subclinical mastitis as determined by WST, SFMT and CMT in dairy cows was very high an indicative of a health and production problems in the smallholder dairy cows farmer in the selected areas of Mymensingh. Consistent with other factors recorded to be associated with mastitis, udder and teat lesions were identified and quantified as number of parity, age, lactation stage of milk production and breed of cows.

\section{REFERENCES}

1. Contreras A, Luengo C, Sanchez A and Corrales JC (2003). The role of intramammary pathogens in dairy goats. Livestock Production Science 79: 273-283.

2. Devi BK, Shukla PC and Bagherwal RK (1997). Incidence of sub-clinical mastitis in cows. Indian Journal Dairy Science 50: 477-478.

3. Egwu GO, Zaria LT, Onyeyili PA, Ambali AG, Adamu SS and Birdling M (1994). Studies on the microbiological flora of caprine mastitis and antibiotic inhibitory concentration in Nigeria. Small Ruminant Research 14: 233-239.

4. Ikram M (1997). Diagnostic microbiology. In: W Paul and V M D Pratt (editors), Laboratory Procedures for Veterinary Technicians. R R Donnelley and Sons Company. St. Louis, Missouri. 159-160 pp.

5. Kader M A, Samad MA, Saha S and Taleb MA (2002). Prevalence and aetiology of sub-clinical mastitis with antibiotic sensitivity to isolated organisms among milch cows in Bangladesh. Indian Journal of Dairy Science 55:218-223.

6. Kahir MA, Islam MA, Rahman AKMA, Nahar A, Rahman MS and Song HJ (2008). Prevalence and risk factors of subclinical bovine mastitis in some dairy farms of Sylhet district of Bangladesh. Korean Journal of Veterinary Services 31(4): 497-504.

7. Majic B, Jovanovic BV, Ljubic Z and Kukovics S (1993). Typical problems encountered in Croatia in the operation of goats milking machines. Proceedings of the $5^{\text {th }}$ Internacional symposium on machine milking of small ruminants. Budapest, Hungary. pp. 377-379.

8. Muhammad G, Athar M, Shakoor A, Khan MZ, Fazal-ur-Rehman and Ahmad MT (1995). Surf Field Mastitis Test: An inexpensive new tool for evaluations of wholesomeness of fresh milk. Pakistan Journal of Food Science 5:91-93.

9. Pal P and Verma BB (1988). Some observation on efficacy of indirect test for detection of sub-clinical mastitis. Indian Journal Veterinary Medicine 8: 40-41.

10. Prodhan MAM, Kamal AHM and Mahbub- E- Elahi ATM (1996). Prevalence of sub-clinical mastitis in cows of Baghabari Milkshed area. Bangladesh Veterinary Journal 30: 59-60.

11. Rabbani AFG (2008). Studies on Bovine Subclinical Mastitis by Using California Mastitis Test. M.S thesis in the Department of Medicine, Bangladesh Agricultural University, Mymensingh.

12. Rahman MS, Nooruddin M and Rahman MM (1997). Prevalence and distribution of mastitis in cross-bred and exotic dairy cows. Bangladesh Veterinary Journal $14: 1-4$

13. Rasool G, Jabbar MA, Kazmi SE and Ahmed A (1985). Incidence of sub-clinical mastitis in Nilli-Ravi buffaloes and Sahiwal cows. Pakistan Veterinary Journal 5: 76-78.

14. Samad MA (2008). Animal Husbandry and Veterinary Science, volume II, LEP pub no.11, Bangladesh Agricultural University campus, Mymensingh.

15. Seegers H, Fourichon C and Beaudeau F (2003). Production effects related to mastitis and mastitis economics in dairy cattle herds> Veterinary Research 34: 475-491.

16. Singh KB and Baxi KK (1988). Studies on the incidence and diagnosis of sub-clinical mastitis in milch animals. Indian Veterinary Journal 47:723-729.

17. Triptahi BV and Chaltopadhyay SK (1993). Caprine mastitis: Clinico morphological and aetipathological findings in spontaneously occuring cases in India goats. International Journal of Animal Science. 8:101-111. 